\title{
SUMMARY
}

Kurnetsova Olga. Methodological system of future musical art teachers' preparation for educational activity with schoolchildren.

The purpose of research is to create and test a model of methodological system for preparing future musical art teachers for educational work in school.

Methods of research are analytically synthesized, comparative, generalization, system-structural and modeling according to the problem of methodological preparation of future musical art teachers for music education.

Results An art-polycentric-centric approach to implementation of methodological preparation for the future education of musical art teachers and students with musical education has been developed, taking into account their creative self-realization. The content, component structure and criterion-level organization of monitoring of the methodological training of future musical art teachers are revealed. The conceptual bases of the methodological system of professional preparation of the future musical art teacher for musical and educational work with students are developed. A methodological system for preparing future teachers of musical art for educational work in the school was created, covering principles, functions, structural components, pedagogical conditions, methodology (organizational forms, methods and stages of implementation) and pedagogical monitoring. The pedagogical conditions of realization of methodological preparation of the future musical art teacher for educational work with students are determined. The system of pedagogical monitoring of the readiness of future teachers of musical art for educational work in school, which involves the use of modern psychological and pedagogical tools, has been improved. The principles of professional training of future musical art teachers to carry out educational activities at school are systematized.

The practical significance of the article is determined by the possibility of using its materials and conclusions in the development of curricula, methodological materials and recommendations on the methodological preparation of the future teacher of musical art for music and educational activities with students in the creation of a new Ukrainian school.

Condusions Created on the basis of polyartistically oriented approach the model of methodological preparation of future teachers of musical art for music and educational activities with students, which covered the purpose and objectives, principles, functions and conditions of music and educational work, component structure, reflective-conscious, communicative-empathic, creative-activity), its criteria, indicators and levels of development of readiness of future musical art teachers.

Key words education, music education, music and educational activities with schoolchildren, professional training of future musical art teachers, model of the methodological system for training students in musical specialties.

удк 378.011.3-051:784

\author{
Чжан ї \\ Національний педагогічний \\ університет імені М. П. Драгоманова \\ ORCID ID 0000-0001-6416-1506 \\ DOI 10.24139/2312-5993/2020.02/404-412
}

\section{МЕТОДОЛОГІЧНІ ОРІЄНТИРИ ФОРМУВАННЯ ВИКОНАВСЬКОї МАЙСТЕРНОСТІ МАГІСТРІВ МУЗИЧНОГО МИСТЕЦТВА}

У статті розглянуто основні методологічні орієнтири формування виконавської майстерності магістрів музичного мистецтва. З’ясовано, що методологічні засади 
підготовки магістрів музичного мистецтва з метою формування їхньої виконавської майстерності розуміються як система узагальнених теоретичних знань, які виконують роль концептуальних позицій, що застосовуються в процесі навчання. Доведено, що формування виконавської майстерності магістрів музичного мистецтва відбувається на основі таких методологічних орієнтирів, як системний підхід, екзистенційна спрямованість, герменевтичний підхід.

Ключові слова: формування, виконавська майстерність, магістри музичного мистецтва, формування виконавської майстерності магістрів музичного мистецтва, методологічні орієнтири.

Постановка проблеми. Науково-практичне усвідомлення освітнього процесу в умовах сьогодення відзначається необхідністю розробки проблеми фахової підготовки магістрів музичного мистецтва. 3'ясування нових можливостей у контексті цієї тематики пов'язано з висвітленням теоретикометодологічного підґрунтя формування виконавської майстерності.

3 цих позицій, провідну ідею даної публікації сконцентровано в розкритті пріоритетних методологічних положень, на яких ґрунтується процес підготовки до публічно-виконавського втілення магістрантів як майбутніх концертних виконавців.

Аналіз актуальних досліджень. Питання магістерської підготовки розроблялися під кутом зору з'ясування вимог до ії змісту за спеціальністю «дизайн» (В. Радкевич), розгляду умов організації навчального процесу в закладах вищої освіти (О. Єременко, А. Козир, І. П’ятницька-Позднякова) та ін.

У сфері мистецтва та педагогіки знайшов своє віддзеркалення вагомий доробок митців та науковців у напрямі обґрунтування специфіки виконавської діяльності. Так, питання підготовки майбутніх фахівців музичного мистецтва до вокально-педагогічної діяльності відображено в роботах Н. Овчаренко; навички вокально-слухового самоконтролю студентів на заняттях із постановки голосу та їх методичні особливості формування досліджували Л. Косяк, М. Павлова; у працях Л. Василенко, Н. Гребенюк, Ю. Мережко, Ю. Юцевича висвітлено проблеми діяльності в сфері вокального мистецтва. У роботах О. Бодіної, Є. Гуренко, М. Давидова, О. Капустіна та ін. розглядається проблема формування виконавської майстерності. Але методологічне підґрунтя формування виконавської майстерності магістрів музичного мистецтва розглянуто обмежено.

Слід підкреслити, що питання успішності формування виконавської майстерності є відображенням тих суперечностей, що виникають між:

- зростанням вимог до якості фахового становлення магістрів музичного мистецтва й усталеною практикою навчання;

- теоретико-виконавською підготовкою студентів магістратури та їх здатністю втілювати набуті компетентності у фаховій роботі;

- необхідністю підготовленості магістрів до сценічного виступу та відсутністю відповідних методів його здійснень. 
Отже, соціально-педагогічна і художньо-методична значущість обраної проблеми, ї̈ недостатня теоретична і практична розробленість зумовили необхідність даної публікації й були основою у визначенні ії теми.

Мета статті полягає в розгляді основних методологічних орієнтирів формування виконавської майстерності магістрів музичного мистецтва.

Для досягнення мети в дослідженні використані загальнонаукові методи: аналітичний - для вивчення педагогічних, психологічних, методичних та мистецтвознавчих джерел 3 метою встановлення теоретичного й практичного рівнів розв'язання проблеми; узагальнення для висвітлення поняттєвого апарату роботи, формулювання ії теоретичних положень та висновків.

Виклад основного матеріалу. Перш ніж висвітлити методологічні орієнтири формування виконавської майстерності магістрів музичного мистецтва, вважаємо за доцільне розглянути сутність таких основних понять, як: «магістр музичного мистецтва», «сценічний виступ», «виконавська майстерність», «методологічні орієнтири».

Обґрунтування особливостей виконавської майстерності магістрів музичного мистецтва пов'язане з розглядом підходів щодо тлумачення поняття «магістр». Так, «магістр» (лат. magister - голова, сановник, начальник, учитель) тлумачиться як другий академічний ступінь, що надається особам у закладі вищої освіти, які склали фаховий іспит та захистили кваліфікаційну роботу (Одерій, 1995).

До того ж, науково-довідкова література тлумачить термін «магістр» як посадову Особу у Стародавньому Римі, а пізніше - в Європі як голови деяких світських і церковних установ (наприклад, Великий Магістр, або гросмейстер, - голова духовно-лицарського ордену).

У довідковій літературі існує визначення магістра як фахівця завершеного освітньо-кваліфікаційного рівня, який на основі вже здобутої кваліфікації бакалавра ґрунтовно засвоїв спеціальні вміння та знання інноваційного характеру та має певний досвід їх продуктивного застосування з метою вирішення проблемних фахових завдань у певній галузі науки, техніки, освіти, культури тощо (Педагогічний словник, 2001).

Крім того, у наукових джерелах зазначається, що підготовка магістрів у системі вищої освіти спрямована на створення умов для творчого розвитку обдарованої особистості та становлення фахівців за одним із функціональних напрямів діяльності: фаховим, науково-дослідним, науково-педагогічним. Особа, яка здобула другий (магістерський) рівень вищої освіти, повинна володіти поглибленими знаннями з обраної спеціальності, уміннями інноваційного характеру, набутим певним досвідом використання одержаних компетенцій і здатністю до створення елементів нових знань із метою з'ясування завдань у відповідній сфері фахової діяльності. 
Так, магістерська підготовка за освітньо-професійною програмою тлумачиться не просто як вищий ступінь становлення фахівців, а як якісно новий її етап і передбачає єдність таких напрямів, як мистецько-фаховий і науково-дослідницький. Звідси, підвищення якості підготовки магістрів музичного мистецтва передбачає орієнтацію навчального процесу на систематичне й послідовне залучення магістрантів до самореалізації в мистецтві та дослідницькій діяльності.

Урахування різноманітних підходів до з'ясування означеної проблеми дає можливість підкреслити, що формування виконавської майстерності магістрів музичного мистецтва як концертних виконавців передбачає формування таких фахових компетенцій, як: здатність усвідомлювати художньо-естетичну природу музичного мистецтва; здатність створювати та реалізовувати власні художні концепції у виконавській діяльності; здатність демонструвати достатньо високий рівень виконавської майстерності; здатність усвідомлювати взаємозв'язки та взаємозалежності між теорією та практикою в сфері музичного мистецтва; здатність оперувати професійною термінологією; здатність збирати, аналізувати, синтезувати художню інформацію й застосовувати її в практичній діяльності.

Отже, формування виконавської майстерності магістрів музичного мистецтва передбачає надбання загальних та фахових компетентностей $з$ метою досягнення таких результатів навчання, як: здатність до прояву артистизму, виконавської культури та технічної майстерності володіння голосом або інструментом на належному фаховому рівні під час вокальновиконавської діяльності; можливість відтворювати драматургічну концепцію музичного твору, створювати його художню інтерпретацію; спроможність демонструвати володіння музично-аналітичними навичками в процесі створення концертно-виконавських інтерпретацій та ін.

Вважаємо за доцільне зазначити, що сценічний виступ у контексті обраної тематики передбачає можливість якнайбільш яскравого презентування себе і здійснення художньо-виконавського перевтілення. Крім того, художньо-переконливе та образно-змістовне виконання має можливість надихати й захоплювати публіку.

Музичне виконавство тлумачиться Є. Гуренком як «вторинна, відносно самостійна творчість, що полягає в процесі конкретизації продукту первинної художньої діяльності (Гуренко, 1982, с. 39). Специфічною ознакою виконавства він визначає наявність художньої інтерпретації. Науковець обґрунтовує художньо-інтерпретаційну природу виконавства, досліджує своєрідність художньої інтерпретації і спростовує її ототожнення з процесом виконання й кінцевим результатом виконавської діяльності музиканта.

Нам імпонує думка О. Бодіної про те, що процесу виконавства притаманні три масштабні рівні творчості. Науковець застосовує семіотичний аналіз до вивчення структури виконавського процесу. Вона 
вказує, що перший елемент пов'язаний із усвідомленням виконавцем змісту окремих мотивів та інтонацій на основі розкриття їх семантичного значення; другий - із переведенням семіотичної конкретизації в художнє узагальнення; третій - із завершенням перших двох і оформленням певного драматургічного задуму виконавця (Бодина, 1992).

Виконавство як повноцінний вид художньої творчості, поряд із діяльністю композитора, драматурга $€$ провідною темою досліджень М. Кагана. До того ж, він відзначає відмінності виконавства, що зумовлені рівнем сформованості особистісних якостей музиканта як виконавця, а також специфічними особливостями художньо-творчої діяльності, суспільною значущістю, цінністю цього виду мистецтва (Каган, 1970).

Ю. Капустін, з точки зору соціології, розглядає особливості сучасного концертного життя, соціальні функції музичного виконавства, форми спілкування між виконавцем і слухачем (Капустін, 1985, с. 12).

Л. Виготський зазначає, що виконавська діяльність зумовлена переживанням чогось значного для індивіда; вона сприяє появі якісних змін психічних властивостей особистості та «якісним новоутворенням» (Виготський, 1967, с. 104). Наявність такого аспекту мотивації впливає на зміст діяльності виконавця, відповідає його інтересам, потребам, художнім орієнтаціям.

Під час викладення матеріалів публікації констатовано, що виокремлення виконавства в особливий вид музично-творчої діяльності вимагає, з одного боку, адекватно осмислити художні результати творчості композитора, як автора музичного твору, а з другого боку, - оптимізації процесу його втілення у виконавській творчості. Виконавська діяльність магістрів музичного мистецтва передбачає втілення їх переживань, які виникають під час сприймання, усвідомлення, опанування художньозмістовного образу музичного твору та інтерпретаційно-виконавської діяльності на публіці (в умовах стресу).

Під кутом зору зазначеного слід підкреслити, що виконавська майстерність М. Давидовим тлумачиться як вільне оволодіння музикантом інструментом і собою, як емоційно яскраве, співтворче, технічно досконале втілення музичного образу в живому звучанні (Давыдов, 1990). О. Шульпяков характеризує різні взаємопов'язані аспекти виконавського мистецтва в контексті взаємодії «художнє» і «технічне» (Шульпяков, 1986). На думку Д.Благого, сутністю процесу формування виконавської майстерності $\epsilon$ необхідність творчого контакту з партнерами у процесі інтерпретації музичного твору (Благой, 1979).

Вважаємо за доцільне в руслі означеної публікації розглянути методологічні орієнтири формування виконавської майстерності магістрів музичного мистецтва. Сукупність найбільш узагальнених ідей та принципів використовується у вирішенні конкретних теоретичних та практичних завдань і являє собою методологію. Слід зазначити, що поняття 
методології характеризується неоднозначністю підходів у тлумаченні. Так, «методологія» як «теорія методів» не означає тільки сукупність методів, способів у досягненні мети. Проблема методології обговорюється у філософії наук, системному підході, синергетиці, феноменології та ін.

Методологія забезпечує наукове обґрунтування, формування ідей та принципів, шляхів і засобів пізнання та практики. Методологічний контекст філософії пов'язаний зі світоглядом, що виступає у вигляді методу та теорії методу. До того ж світоглядна функція передбачає певне ставлення особистості до світу. За умов, коли світогляд починає виконувати роль активного регулятора діяльності, то він виступає в ролі методології.

Класифікація методології на загальну та конкретну уможливлює, поперше, розуміння ії̈ як «загальної системи теоретичних знань, що виконують роль провідних принципів наукового пізнання, шляхів та засобів реалізації наукового дослідження», а, по-друге, - як «теорії наукового пізнання в конкретній галузі науки» (Філософія, 2004, с. 48-49).

У контексті нашої роботи доцільно підкреслити, що методологія займається теоретичними проблемами шляхів і засобів наукового пізнання та закономірностей наукового дослідження як творчого процесу (Вітвицька, 2003, с. 24). Особливості сучасного стану підготовки фахівців музичного мистецтва впливає на вибір теоретико-методологічних стратегій і методів навчання. Так, Г. Падалка тлумачить методологічні засади в системі освіти як найбільш узагальнені концептуальні положення, дія яких розповсюджується на все поле педагогічної діяльності (Падалка, 2008, с. 42). Отже, методологічні засади підготовки магістрів музичного мистецтва з метою формування їхньої виконавської майстерності розуміються як система узагальнених теоретичних знань, які виконують роль концептуальних позицій, що застосовуються в процесі навчання.

Формування виконавської майстерності магістрів музичного мистецтва відбувається на основі системного підходу, який сприяє відтворенню цілісності процесів творчості, їх дослідження в певній ієрархії рівнів.

Одним із провідних методологічних орієнтирів означеного процесу $\epsilon$ екзистенційна спрямованість мистецького навчання в магістратурі. Життя людини - екзистенція - відкрито для безпосереднього переживання та емоційного відчуття. Слід зазначити, що музичний твір є засобом, який віддзеркалює його екзистенцію. Тобто, музичний твір має екзистенціальну природу, тому що його образи відзначаються емоційним переживанням. Ця позиція виглядає таким чином: тільки те існування, те мислення, що виходить із екзистенції, можна вважати справжнім у виконавця.

Надбання як філософської, так і психологічної думки дають можливість розглядати проблему екзистенції під час підготовки магістрів музичного мистецтва у контексті особливостей ментальності українців. її провідною ідеєю є необмежена свобода, визнання рівного права кожної 
людини в суспільстві. Під таким кутом зору, творчий індивідуалізм, що сформувався у глибинах самого способу життя предків, виявляється у здатності й бажанні брати на себе відповідальність за вибір і результати діяльності та суспільного життя. Тобто, формування творчого індивідуалізму з урахуванням особливостей психіки українців, сприяє здійсненню особистісного вибору рішень за внутрішнім ідеалом і впливає на розвиток ініціативності, самостійності, уміння володіти собою. Крім того, волелюбність українців входить у контекст їх екзистенційності.

Екзистенція як життєвий досвід, що наповнюється емоціями, активізує внутрішній світ особистості та впливає на їі прагнення до самопізнання, заглибленості в себе, на формування духовного світу, поєднаного з особистісними якостями людини.

Отже, екзистенція пов'язана з емоціями. У довідковій літературі емоції (термін «емоції» від лат. emoveo - зворушую, хвилюю) визначаються як процес ситуативного переживання, ставлення до навколишніх об'єктів, реакції на зовнішні і внутрішні подразники, що мають для організму сигнальне й регулювальне значення. Емоції людини віддзеркалюють ставлення особистості до навколишньої діяльності і до самої себе.

У контексті вищезазначеного забезпечення підготовки магістрів музичного мистецтва передбачає розвиток у них безсвідомої сфери. Адже виконавська діяльність забезпечується розвиненою інтуїцією та образним осмисленням художнього твору. Розгляд екзистенційно-емоційних процесів у музичній педагогіці базується на сучасних психологічних теоріях емоцій, у яких розглядаються єдність «афекту й інтелекту», пізнавальних емоційних способів освоєння дійсності. Теорія емоцій (за Б. Додоновим) визнає функцію емоційного оцінювання зовнішнього і внутрішнього світу. Отже, одним із провідних теоретичних положень виступає думка щодо емоційної насиченості навчального процесу в магістратурі, що виявляється в орієнтації майбутнього фахівця на певні переживання, які надають додаткової цінності мистецькими явищам і музично-виконавській діяльності.

Герменевтичний підхід як спосіб інтерпретації тексту полягає в тому, щоб передати будь-який його смисл з урахуванням позицій, думок і оцінок виконавця. Слід підкреслити, що не має остаточного кінцевого смислу твору, а існує відносна свобода його інтерпретації. Герменевтичний підхід дозволяє завдяки особливостям стилю, мови, побудови фрази і всього твору в цілому осягнути його як музичний образ, створений автором, і дати можливість виконавцю здійснити творчий акт відтворення художнього явища, орієнтуватися в способах композиторського замислу.

Вищезазначене свідчить про те, що застосування варіативності під час формування виконавської майстерності магістрів музичного мистецтва має вагоме значення. Варіативність передбачає розвиток варіативного мислення, розуміння можливості різних варіантів з'ясування завдань, 
уміння здійснювати систематичний обґрунтований вибір варіантів, їх порівнювати та знаходити оптимальний спосіб дій.

Висновок та перспективи подальших наукових розвідок. Отже, матеріали публікації дають можливість стверджувати про актуальність та доцільність обраної проблеми формування виконавської майстерності магістрів музичного мистецтва та свідчать про наявність низки питань, що потребують більш повного висвітлення, зокрема, - у напрямі методичного забезпечення формування означеного феномену.

\section{ЛІТЕРАТУРА}

Вітвицька, С. С. (2003). Основи педагогіки вищої школи: методичний посібник для студентів магістратури. Житомир: Житомирський пед. університет (Vitvytska, S. S. (2003). Fundamentals of higher school pedagogy: a guide for graduate students. Zhytomyr: Zhytomyr ped. university).

Одерій, Л. П. (1995). Оцінка в міжнародній системі освіти: методологія та інструментарій. Київ: КДЕУ (Oderii, L. Р. (1995). Assessment in the international education system: methodology and tools. Kyiv: KSEU).

Падалка, Г. М. (2001). Педагогіка мистецтва (теорія і методика викладання мистецьких дисциплін). К.: Освіта України (Padalka, Н. М. (2001). Art pedagogy (theory and methods of teaching art disciplines). K.: Education of Ukraine).

Педагогічний словник (2001). Київ: Педагогічна думка (Pedagogical Dictionary (2001). Kyiv: Pedagogical thought).

Філософрія: підручник для вищої школи (2004). Харків: Прапор (Philosophy: a textbook for higher school (2004). Kharkiv: Flag).

Гуренко, Е. Г. (1982). Проблемы художественной интерпретации: философский анализ. Новосибирск: Наука (Hurenko, Е. Н. (1982). Problems of artistic interpretation: philosophical analysis. Novosibirsk: Science).

Каган, М. С. (1970). Морфология искусства: историко-теоретическое исследование внутреннего строения мира искусств. Л.: Искусство (Kagan, М. S. (1970). Morphology of art: historical and theoretical study of the internal structure of the art world. L.: Art).

Бодина, Е. А. (1992). Воспитательные фуннкции музыки: эволюция и современные тенденции реализации (автореф. дис. ... доктора пед. наук). M. (Bodina, E. A. (1992). Educational functions of music: evolution and modern tendencies of realization (DSc thesis). M.).

Капустин, Ю. В. (1985). Музыкант-исполнитель и слушатель. Л.: Музыка (Kapustin, Yu. V. (1985). M usician-performer and listener. L.: M usic).

Виготський, Л. С. Уявлення і творчість в дитячому віці. М.: Просвещение (Vygotsky, L. S. Imagination and creativity in childhood. M .: Enlightenment).

Давыдов, Н. А. (1990). Теоретические основы формирования исполнительского мастерства баяниста (автореф. дис. ... д-ра искусствоведения: 17.00.02. К. (Davydov, N. A. (1990). Theoretical bases of the accordionist's performing skills formation (PhD thesis abstract)).

Шульпяков, О. Ф. (1986). Музыкально-исполнительская техника и художественный образ: Психофизиологическое единство исполнительской деятельности. Проблемы методологии (автореф. дис. ... д-ра искусствовед.: 7.00.02). М. (Shulpiakov, O. F. (1986). Musical-performing technique and artistic image: Psychophysiological unity of performing activity. Problems of methodology (DSc thesis abstract)). 
Благой, Д. (1979). Искусство камерного ансамбля и музыкально-педагогический процесс. Камерный ансамбль: Педагогика и исполнительство. М.: Музыка (Blahoi, D. (1979). The art of the chamber ensemble and the musical-pedagogical process. Chamber ensemble: Pedagogy and performance. $M$.: M usic).

\section{PEЗЮME}

Чжан И. Методологические ориентиры формирования исполнительского мастерства магистров музыкального искусства.

В статье рассмотрены основные методологические ориентиры формирования исполнительского мастерства магистров музыкального искусства. Выяснено, что методологические основы подготовки магистров музыкального искусства с целью формирования их исполнительского мастерства понимаются как система обобщенных теоретических знаний, которые выполняют роль концептуальных позиций, которые применяются в процессе обучения. Доказано, что формирование исполнительского мастерства магистров музыкального искусства происходит на основе таких методологических ориентиров, как системный подход, экзистенциональная направленность, герменевтический подход.

Ключевые слова: формирование, исполнительское мастерство, магистры музыкального искусства, формирование исполнительского мастерства магистров музыкального искусства, методологические ориентиры.

\section{SUMMARY}

Zhang I. Methodological guidelines for the formation of musical art masters' performing skills.

The article discusses the main methodological guidelines for the formation of musical art masters' performing skills. It was found out that methodological foundations of the preparation of musical art masters with the aim of forming their performing skills are understood as a system of generalized theoretical knowledge that plays the role of conceptual positions that are applied in the process of learning. It is proved that the formation of musical art masters' skills takes place on the basis of such methodological guidelines as a systematic approach, an existential orientation, a hermeneutic approach.

Consideration of existential-emotional processes in music pedagogy is based on modern psychological theories of emotions, which consider the unity of "affect and intellect", cognitive emotional ways of mastering reality. The theory of emotions recognizes the function of emotional evaluation of the external and internal world. Thus, one of the leading theoretical positions is the idea of emotional saturation of the educational process in the master's degree, which is manifested in the orientation of the future specialist to certain experiences that give additional value to artistic phenomena and musical performance.

The hermeneutic approach as a way of interpreting the text is to convey any of its meaning, taking into account the positions, opinions and assessments of the performer. It should be emphasized that there is no final meaning of the work, but there is a relative freedom of its interpretation. Hermeneutic approach allows due to the peculiarities of style, language, phrase construction and the whole work to comprehend it as a musical image created by the author and allow the performer to perform a creative act of reproduction of an artistic phenomenon, to navigate in the ways of composition.

It is proved that application of variability in the formation of performing skills of musical art masters is important. Variability involves development of variable thinking, understanding the possibility of different options for clarifying tasks, ability to make a systematic informed choice of options, compare them and find the best course of action.

Key words: formation, mastery, masters of musical art, formation of musical art masters' skills, methodological guidelines. 